\title{
New Records of Species of Gebiidea and Anomura (Crustacea: Decapoda) from the Sea of Japan
}

\author{
Masayuki Osawa ${ }^{1,3}$ and Yuzo Ota ${ }^{2}$ \\ ${ }^{1}$ Estuary Research Center, Shimane University, 1060 Nishikawatsu-cho, Matsue, Shimane 690-8504, Japan \\ E-mail: osawam@soc.shimane-u.ac.jp \\ ${ }^{2}$ San'in Kaigan Geopark Museum of the Earth and Sea, 1794-4 Makidani, Iwami, Tottori 681-0001, Japan \\ ${ }^{3}$ Corresponding author
}

(Received 5 December 2019; Accepted 9 July 2020)

\begin{abstract}
Six decapod crustacean species, including one gebiidean and five anomurans, are reported as new to the marine fauna in the Sea of Japan based on material collected from the coast of Tottori Prefecture, western Japan. Among them, the munidid squat lobster Paramunida tricarinata (Alcock, 1894) is new to the Japanese fauna. In addition to the six species, the occurrence of the diogenid hermit crab Paguristes versus Komai, 2001 in the Sea of Japan is confirmed on the basis of specimens newly obtained from Tottori Prefecture. The current knowledge on the fauna of Gebiidea and Anomura in the western Japanese coast of the Sea of Japan is also briefly summarized.
\end{abstract}

Key Words: Mud shrimp, hermit crab, squat lobster, fauna, biogeography, San’in area, East Asia.

\section{Introduction}

The Sea of Japan is the marginal, semiclosed sea surrounded by the Eurasian Continent, Sakhalin, and two Japanese main islands (Hokkaido and Honshu). It is connected to the Pacific Ocean by five shallow straits from the north to south: Strait of Tartary (=Mamiya Strait), La Pérouse Strait (=Soya Strait), Tsugaru Strait, Kanmon Straits, and Tsushima Strait (Fig. 1A). The Tsushima Current brings warmer and more saline water to the north along the coast of Honshu, merges into the Tsugaru Current, and primary flows into the Pacific Ocean through the Tsugaru Strait. This encourages the warm marine fauna in its richness and that the distribution of tropical water species particularly in the western area as the "inflow gate" to the Sea of Japan for the Tsushima Current. The western area "San'in" is composed of the marine coasts of five Japanese prefectures from the west to east: Yamaguchi, Shimane, Tottori, Hyogo, and Kyoto (Fig. 1B). Nishimura (1992) discussed on seven zoogeographical (zooclimatic) zones categorized in Japanese waters (tropical, subtropical, warm temperate, moderate temperate, cool temperate, subboreal, and boreal zones) and suggested the area around Shimane Prefecture to be a boundary between the warm temperate and moderate temperate zones in the coast of the Sea of Japan. In "San'in" area, the fauna of decapod crustaceans in Shimane and Tottori Prefectures is relatively well compiled by recent studies ( $c f$. Takeda et al. 2011, for Brachyura; Osawa et al. 2014b, 2015, 2016, 2018, for Anomura), but their inventory is still incomplete.

The second author has collected marine invertebrate specimens in order to understand the coastal fauna of Tottori Prefecture (Fig. 1C). The present paper reports on one gebiidean [Austinogebia narutensis (Sakai, 1986)] and five anomuran species [Paguristes gonagrus (H. Milne Edwards, 1836) (Diogenidae); Nematopagurus australis (Henderson, 1888) (Paguridae); Galathea guttata Osawa, 2004 (Galatheidae); Munida agave Macpherson and Baba, 1993, and Paramunida tricarinata (Alcock, 1894) (Munididae)] as new additions to the decapod crustacean fauna in the Sea of Japan, with a brief summary of the current knowledge on the fauna of Gebiidea and Anomura in the western Japanese coast of the Sea of Japan. This study only contains a finding of a single species (Paramunida tricarinata) new to the entire fauna of Japanese waters and gives some new information on the local fauna. However, we believe it is valuable to supplement rather little knowledge on the marine invertebrate fauna in the coast of the Sea of Japan, for further succeeding studies.

\section{Materials and Methods}

The collection localities of the present specimens are shown in Fig. 1C. The specimens examined were collected by using SCUBA (depths of $10-26 \mathrm{~m}$ ) and beam trawls (depths of 50-120 m), except those of Austinogebia narutensis which lack the data of the collection method and depth. The approximate latitude and longitude are given for the collection localities of the specimens. Specimen size is indicated as following: for Upogebiidae (mud shrimps), the carapace length ( $\mathrm{cl}$, in $\mathrm{mm}$ ), measured from the tip of the rostrum to the midpoint of the posterodorsal margin of the carapace; for Diogenidae and Paguridae (hermit crabs), the shield length (sl), from the tip of the rostrum to the midpoint of the posterior margin of the shield; and for Galatheidae and Munididae (squat lobsters), the postorbital carapace length ( $\mathrm{pcl}$ ), along the dorsal midline from the posterior margin of the orbit to the posterior margin of the carapace. 

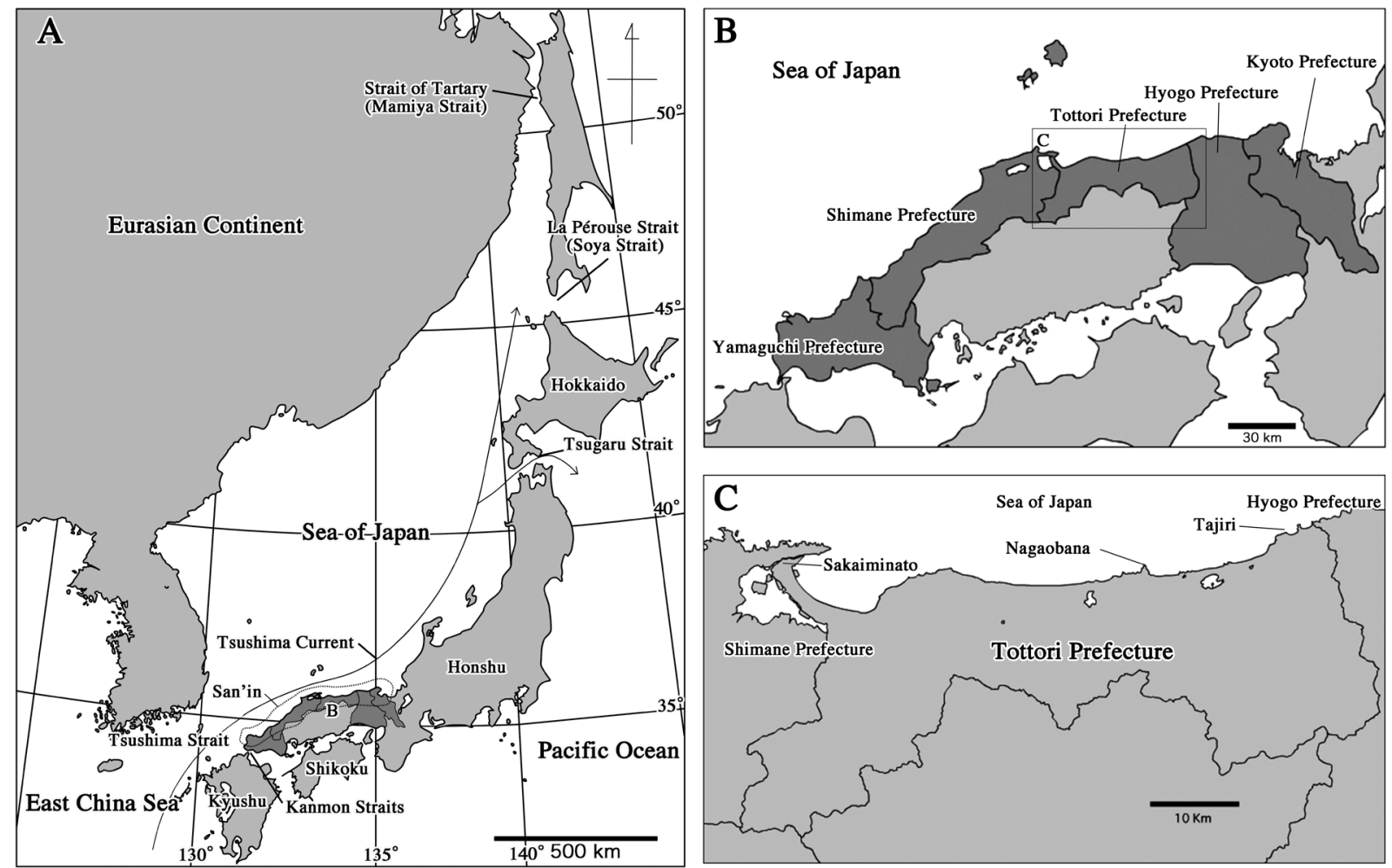

Fig. 1. Maps of studied region. A, Japanese main islands and their adjacent areas, showing the Sea of Japan and "San'in” area, western Japanese coast of the sea; B, "San'in" area composed of five Japanese prefectures (Yamaguchi, Shimane, Tottori, Hyogo, and Kyoto); C, localities in Tottori Prefecture (Sakaiminato, Nagaobana, and Tajiri) from which the present specimens were collected.

All the material is deposited in the collection of the Tottori Prefectural Museum, Tottori (TRPM).

In this study, according to Motoh (2007), the Japanese area of the Sea of Japan is defined as coasts and off-shores from Yamaguchi Prefecture (Kammon Straits) to Hokkaido Prefecture (Soya Strait).

\section{Systematic Account}

Infraorder Gebiidea de Saint Laurent, 1979

Family Upogebiidae Borradaile, 1903

Austinogebia narutensis (Sakai, 1986)

(Fig. 2A-D)

Upogebia major (non De Haan, 1841): Miyake 1982: pl. 31, fig. 5.

Upogebia spinifrons non Haswell, 1881: Sakai 1984: 209, figs $1-3$.

Upogebia narutensis Sakai, 1986: 25, pl. 1 (type locality: Ohge-Jima, Naruro, Tokushima Prefecture, Japan; low intertidal); Ngoc-Ho 1994: 198, figs 4, 5 (in part); Sakai 2006: 130.

Austinogebia narutensis: Ngoc-Ho 2001: 50, fig. 3; Sato et al. 2016: 36, fig. 5A.

Material examined. Tottori Prefecture. Off Sakaiminato $\left(35^{\circ} 52^{\prime} \mathrm{N}, 133^{\circ} 31^{\prime} \mathrm{E}\right), 16$ October 2006 , coll. M. Nagata, 1 male (cl $17.9 \mathrm{~mm}), 3$ females (cl 16.7-18.9 mm), TRPM-780.
Distribution. Japan and Taiwan; lower intertidal to depths of 5-30 m (Sakai 2006, as Upogebia narutensis). Japanese records include Ibaraki, Shizuoka, Wakayama, Hiroshima, Tottori, Yamaguchi (Honshu mainland), Tokushima, Kochi (Shikoku mainland), and Kagoshima (Kyushu mainland) Prefectures (Itani 2004; Sakai 2006; Sato et al. 2016; present study). The present specimens reveal the first record of this species from the Sea of Japan.

Habitat. Seashore, sand or muddy sand (Itani 2004). In the Seto Inland Sea, Austinogebia narutensis is sympatric with Upogebia issaeffi (Balss, 1913) on sandy shores and with U. major (De Haan, 1841) on a muddy shore (Itani 2004); whereas in Kashima-nada, Ibaraki Prefecture, A. narutensis inhabits subtidal fine-sand bottom in open coast (Sato et al. 2016). The structure of burrows of A. narutensis was studied in detail by Kinoshita and Itani (2005).

Remarks. The genus Austinogebia Ngoc-Ho, 2001 now includes eight species (cf. Liu and Sha 2015) and among them, only A. narutensis and A. wuhsienweni (Yu, 1931) have been recorded from Japanese waters (Sakai 2006). Austinogebia narutensis is characterized by the rostrum being 1.2-1.5 times as long as broad at the base, the anterior half of the rostrum being unarmed dorsally, the third article of the antennal peduncle with a distal spine on the lower margin, and the merus of the second pereopod with a distal spine on the upper margin (Ngoc-Ho 2001). This species has been recorded from the southwestern coast of Kyushu (Izumi, Kagoshima Prefecture; Sakai 2006). The present record of A. narutensis in the Sea of Japan suggests that the 

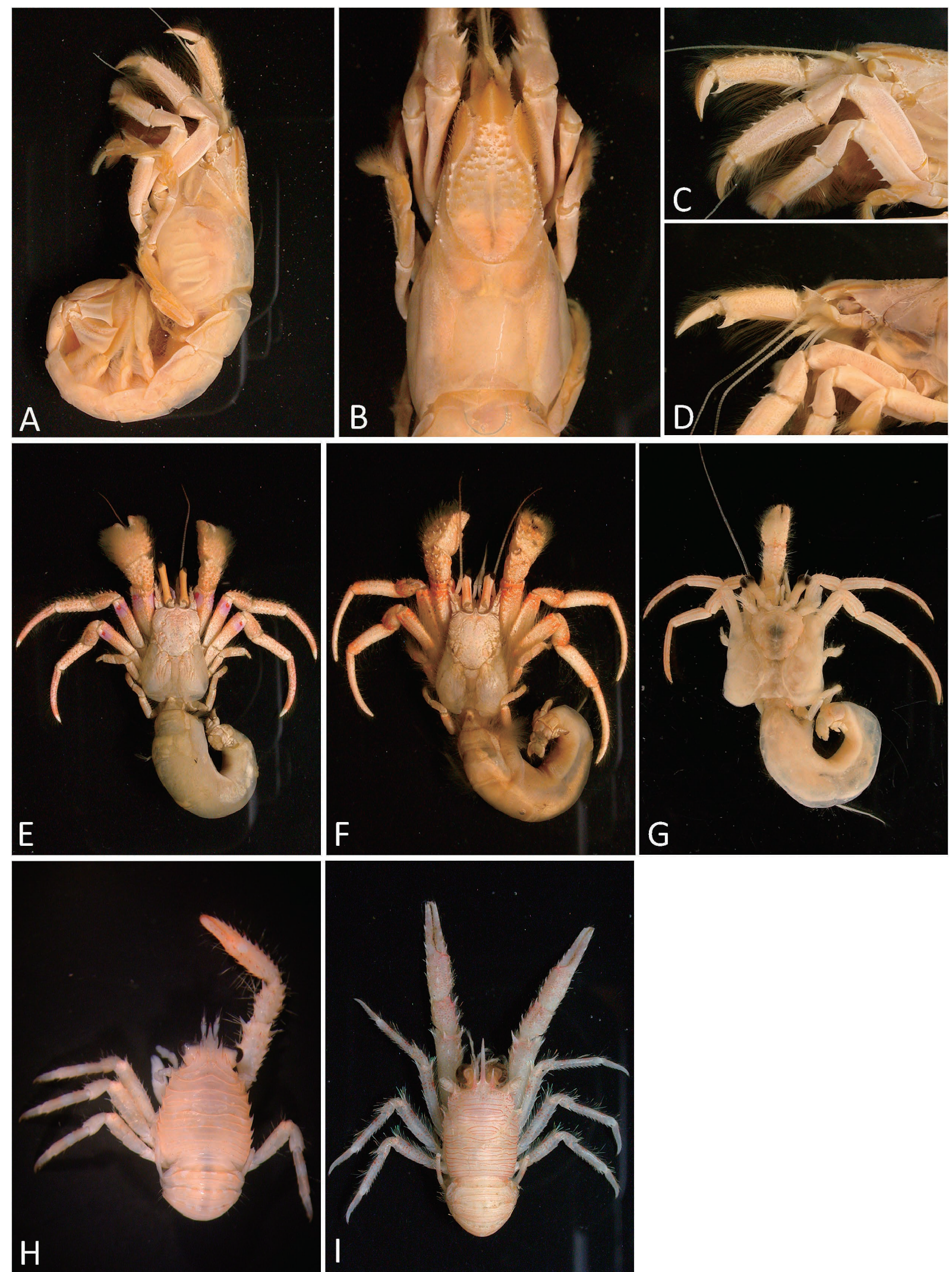

G

Fig. 2. Preserved specimens. A, Austinogebia narutensis (Sakai, 1986), female (cl $18.9 \mathrm{~mm}$ ), TRPM-780, left lateral view; B, same, carapace, dorsal view; C, same, left lateral view, anterior part of body, showing pereopod 1; D, Austinogebia narutensis (Sakai, 1986), male (cl 17.9 mm), TRPM-780, left lateral view; E, Paguristes gonagrus (H. Milne Edwards, 1836), male (sl $6.4 \mathrm{~mm}$ ), TRPM-782, dorsal view; F, Paguristes versus Komai, 2001, male (sl $5.8 \mathrm{~mm}$ ), TRPM-783, dorsal view; G, Nematopagurus australis (Henderson, 1888), female (sl 4.3 mm), TRPM-784, dorsal view; H, Galathea guttata Osawa, 2004, male (pcl $3.1 \mathrm{~mm}$ ), TRPM-785, dorsal view; I, Munida agave Macpherson and Baba, 1993, ovigerous female (pcl $7.4 \mathrm{~mm})$, TRPM-788, dorsal view. 
species is also distributed in the northwestern coast of Kyushu, although no records of the species from the area are available so far

\section{Infraorder Anomura MacLeay, 1838 \\ Family Diogenidae Ortmann, 1892 \\ Paguristes gonagrus (H. Milne Edwards, 1836)}

(Figs 2E, 3A)

\section{Restricted synonymy.}

Pagurus gonagrus H. Milne Edwards, 1836: 281 (type locality: China Sea).

Paguristes gonagrus: Alcock 1905: 155 (list); Rahayu and Forest 2009: 1312, figs 1, 2; Komai 2010: 10, figs 1-5 (compilation).

Paguristes balanophilus non Alcock, 1905: Miyake 1978: 40, text-fig. 14, pl. 2, fig. 7; Miyake 1982: 97, pl. 33, fig. 1; Minemizu 2000: 131, unnumbered fig.

Material examined. Tottori Prefecture. Off Nagaobana $\left(35^{\circ} 55^{\prime} \mathrm{N}, 134^{\circ} 00^{\prime} \mathrm{E}\right)$, Tottori: $50 \mathrm{~m}$, beam trawl, 13 July 2018, coll. Y. Ota, 1 male (sl $5.6 \mathrm{~mm}$ ), TRPM-781; $50 \mathrm{~m}$, beam trawl, 20 August 2018, coll. Y. Ota, 1 male (sl $6.4 \mathrm{~mm}$ ), TRPM-782.

Distribution. Japan, Taiwan, China Sea, Bohol in the Philippines; depths of 13-200m (Komai 2010). Japanese records include the Pacific coast from Sagami Bay to the Ryukyu Islands, and Tottori Prefecture on the coast of the Sea of Japan (Komai 2010; present study). The present specimens reveal the first record of this species from the Sea of Japan.

Habitat. Muddy sand; found in various species of gastropod shells, which are always encrusted with Epizoanthus Gray, 1867 (Cnidaria: Anthozoa: Zoantharia: Epizoanthidae) (Minemizu 2000; Komai 2010). The present specimens were collected from the bottom containing dead shells and gravels.

Remarks. Paguristes gonagrus has been confounded with P. balanophilus Alcock, 1905 in Japanese literature (cf. Miyake 1978, 1982). The true identities of the two species were clarified by the re-examinations of respective type specimens by Rahayu and McLaughlin (2006) and Rahayu and Forest (2009) and a subsequent detailed description of $P$. gonagrus by Komai (2010). Paguristes gonagrus is distinctive among Japanese congeners and practically distinguished by the dense covering of long soft setae on the dorsal surface of each chela, which obscure or conceal the armature, and the lateral surfaces of the meri of the chelipeds and ambulatory legs each with a small red spot distally, which is circumscribed by a broad violet ring ( $c f$. Komai 2010).

Paguristes versus Komai, 2001

(Figs 2F, 3B)

\section{Restricted synonymy.}

Paguristes kagoshimensis non Ortmann, 1892 (= Paguristes digitalis Stimpson, 1858): Kim 1973: 214, 597, fig. 44, pl. 69, fig. 25; Miyake 1978; 35, fig. 12; Miyake 1982: 96, pl.
32, fig. 5 .

Paguristes versus Komai, 2001: 406, figs 23-27 (type locality: Okinoyama Bank, Sagami-nada, Japan, 34 $59^{\prime} \mathrm{N}$, $139^{\circ} 39^{\prime} \mathrm{E}$; 105-113 m); McLaughlin et al. 2007: 54, 2 unnumbered figs.

Material examined. Tottori Prefecture. Off Nagaobana $\left(35^{\circ} 55^{\prime} \mathrm{N}, 134^{\circ} 00^{\prime} \mathrm{E}\right)$, Tottori, $100 \mathrm{~m}$, beam trawl, 15 May 2018, coll. Y. Ota, 3 males (sl 4.9-5.8 mm), TRPM-783.

Distribution. Japan, Korea, Taiwan; 80-221 m, possibly to $254 \mathrm{~m}$ (Komai 2001; McLaughlin et al. 2007). Japanese records include the Pacific coast from Boso Peninsula to the Ohsumi Islands, northern Ryukyu Islands (Komai 2001), and Toyama and Tottori Prefectures on the coast of the Sea of Japan (Kikuchi 1932, as P. kagoshimensis Ortmann, 1892; present study).

Habitat. No previous records on the collection substrate, but sampling gears mentioned in the previous literature (e.g., Komai 2001; McLaughlin et al. 2007) suggest that specimens of $P$. versus were collected from soft bottoms. The present specimens were collected from the muddy sand substrate.

Remarks. This species had been referred to as Paguristes kagoshimensis in previous literature (cf. Miyake 1978, 1982). With the reexamination of the type material of $P$. kagosimaensis, Komai (2001) clarified that P. kagoshimensis was actually conspecific with $P$. digitalis Stimpson, 1858, and assigned the taxon confounded with P. kagoshimensis to his new species $P$. versus. The occurrence of $P$. versus from the Sea of Japan has been confirmed by the present specimens, although Kikuchi (1932) had recorded "P. kagoshimensis" from Toyama Bay in the area.

Four species of the genus Paguristes Dana, 1851 are now known from the Sea of Japan with the addition of the two species recorded in this paper: $P$. digitalis, $P$. gonagrus, $P$. ortmanni Miyake, 1978, and P. versus (cf. Motoh 2007; present study). Two species of the allied genus Areopaguristes Rahayu and McLaughlin, 2010, A. hirsutimanus (Kobjakova, 1971) (junior synonym: Stratiotes nigroapiculus Komai, 2009) and A. japonicus (Miyake, 1961), are also known from the Sea of Japan (Motoh 2007, as Paguristes; Komai 2009, as Stratiotes Thomson, 1899; Marin 2016).

Family Paguridae Latreille, 1802

Nematopagurus australis (Henderson, 1888)

(Figs 2G, 3C)

\section{Restricted synonymy.}

Catapagurus australis Henderson, 1888: 76, pl. 8, fig. 1 (type locality: Arafura Sea, Challenger stn 188, 09 $59^{\prime} \mathrm{S}$, $139^{\circ} 42^{\prime} \mathrm{E} ; 51 \mathrm{~m}$ ).

Nematopagurus australis: McLaughlin 1997: 505; McLaughlin 2004: 221, fig. 26; Komai and Takeda 2006: 99; McLaughlin et al. 2007: 234, 2 unnumbered figs.

Nematopagurus cf. australis: McLaughlin 2002: 436, fig. $7 \mathrm{~F}-\mathrm{H}$.

Material examined. Tottori Prefecture. Off Nagaobana 

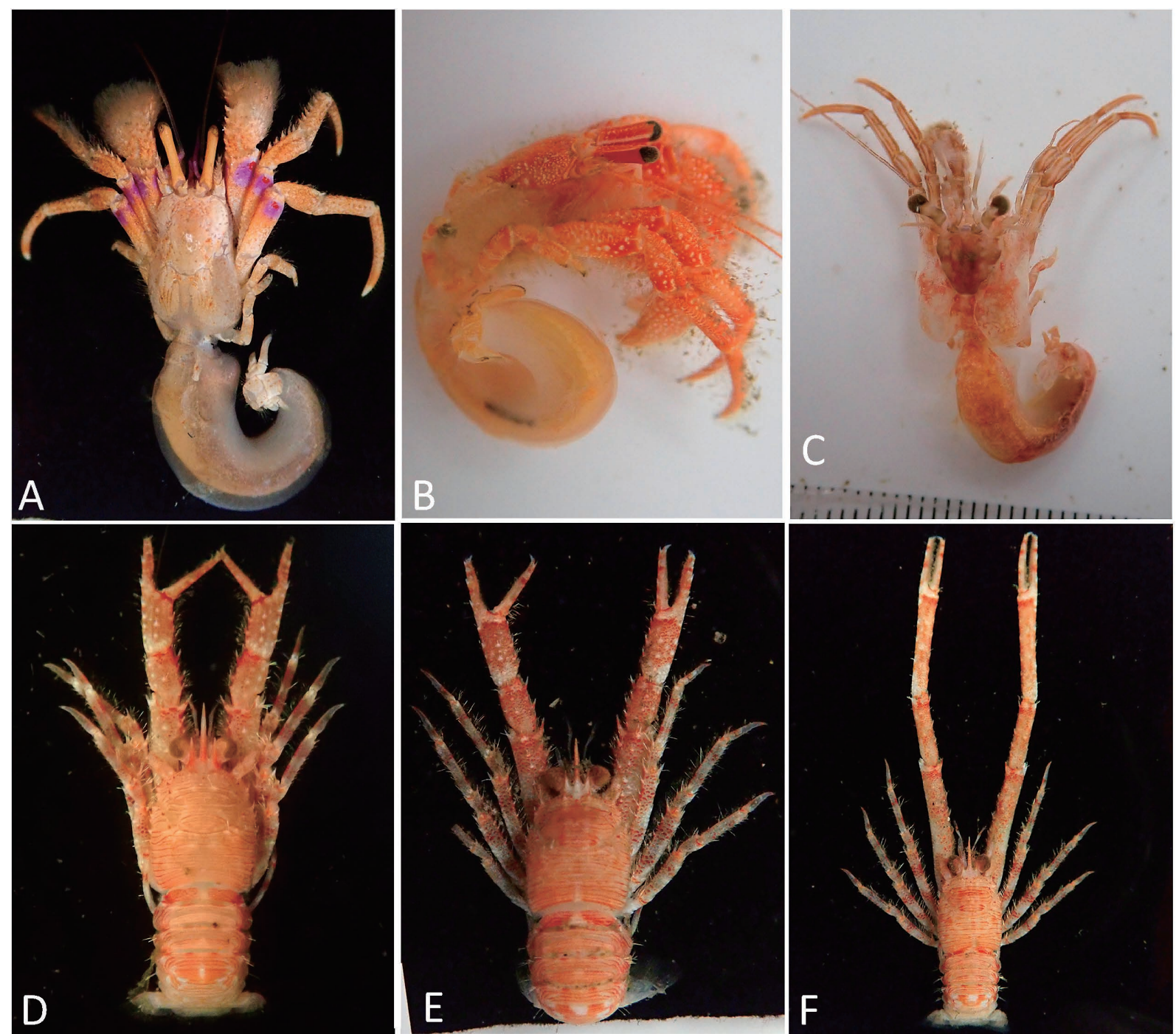

D
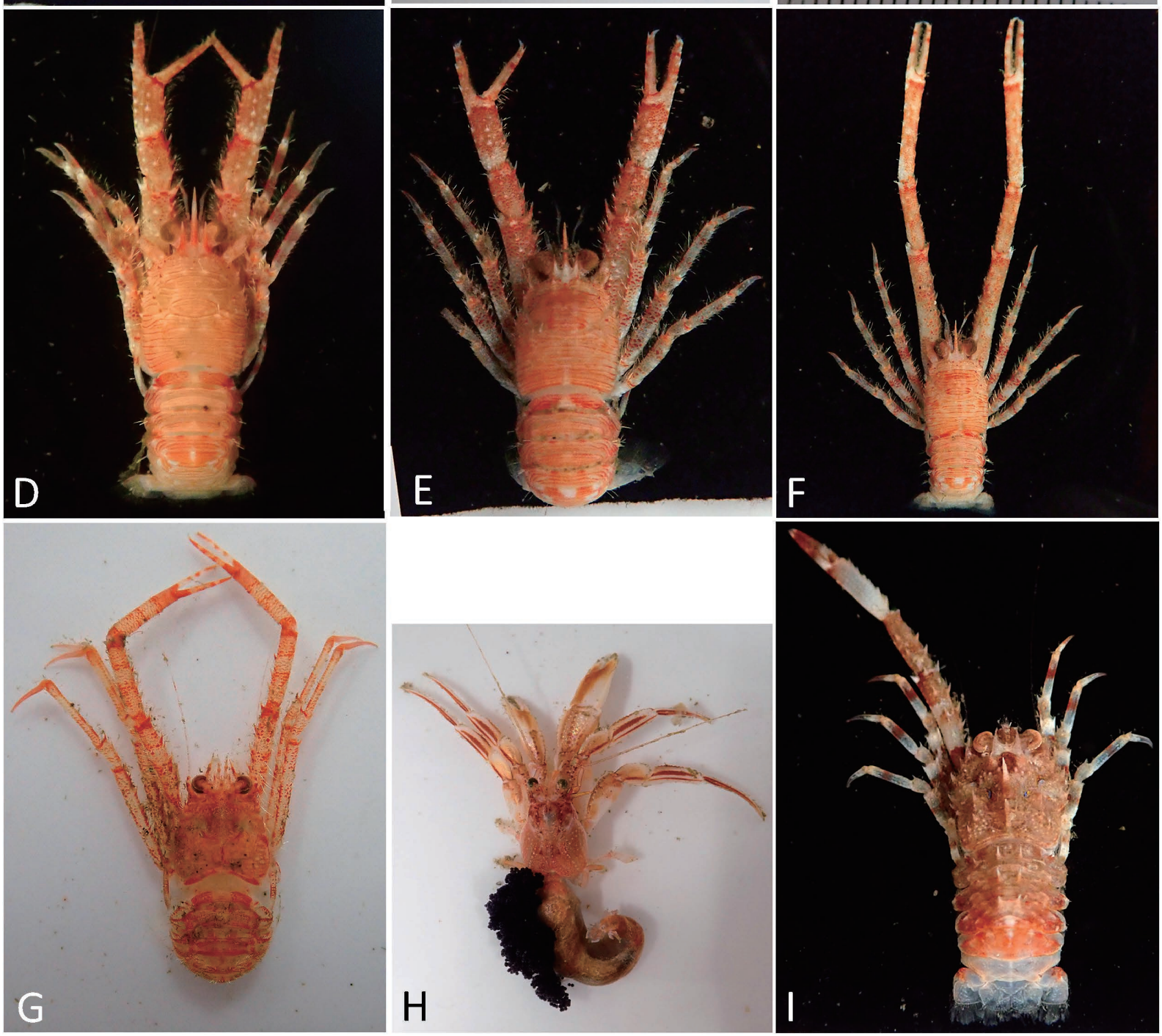

Fig. 3. Fresh specimens. A, Paguristes gonagrus (H. Milne Edwards, 1836), male (sl $6.4 \mathrm{~mm}$ ), TRPM-782, dorsal view; B, Paguristes versus Komai, 2001, male (sl $5.8 \mathrm{~mm}$ ), TRPM-783, right lateral view; C, Nematopagurus australis (Henderson, 1888), female (sl 4.3 mm), TRPM784, dorsal view; D, Munida agave Macpherson and Baba, 1993, ovigerous female (pcl 7.5 mm), TRPM-787, dorsal view; E, Munida pherusa Macpherson and Baba, 1993, ovigerous female (pcl $7.7 \mathrm{~mm}$ ), TRPM-802, dorsal view; F, Munida pherusa Macpherson and Baba, 1993, male (pcl $6.6 \mathrm{~mm}$ ), TRPM-802, dorsal view ; G, Paramunida tricarinata (Alcock, 1894), ovigerous female (pcl 7.9 mm), TRPM-790; H, Pagurus nipponensis (Yokoya, 1933), ovigerous female (sl $5.9 \mathrm{~mm}$ ), TRPM-798; I, Bathymunida brevirostris (Yokoya, 1933), female (pcl $5.4 \mathrm{~mm}$ ), TRPM-801. 
$\left(35^{\circ} 55^{\prime} \mathrm{N}, 134^{\circ} 00^{\prime} \mathrm{E}\right)$, Tottori, $100 \mathrm{~m}$, beam trawl, 15 May 2018, coll. Y. Ota, 1 female (sl $4.3 \mathrm{~mm}$ ), TRPM-784.

Distribution. Japan, Taiwan, South China Sea, Malaysia, Indonesia, New Caledonia, and Fiji; subtidal to $292 \mathrm{~m}$, possibly to $417 \mathrm{~m}$ (McLaughlin 2004). Japanese records include Suruga and Sagami Bays and Tottori Prefecture in Honshu mainland (McLaughlin 2004; Komai and Takeda 2006; present study). The present specimen reveals the first record of this species from the Sea of Japan.

Habitat. Syntypes collected from green mud substrate and reef (McLaughlin 2004). The present specimen was collected from the muddy sand substrate.

Remarks. Although the right cheliped of the present specimen is missing, there is no doubt on the species identification because the specimen has other characters diagnostic to $N$. australis such as the left chela unarmed or with a median row of small spines on the dorsal surface, the dactylus of the left cheliped with a row of spines on the dorsomesial margin; and the dactylus of the left third pereopod being more than 1.5 length of the propodus, prominently curved ventrally and twisted, and with ventral marginal spines not clearly visible in lateral view ( $c f$. McLaughlin 2004; McLaughlin et al. 2007).

\section{Family Galatheidae Samouelle, 1819 Galathea guttata Osawa, 2004}

(Fig. 2H)

Galathea sp. B: Kato and Okuno 2001: 88, unnumbered fig. Galathea guttata Osawa, 2004: 93, figs 1, 2, 3A, B (type locality: Kume Island, Ryukyu Islands, Japan; $18 \mathrm{~m}$ ); Baba et al. 2008: 69; Dong and Li 2010: 11, fig. 6; Macpherson and Robainas-Barcia 2015: 133.

Material examined. Tottori Prefecture. Off Tajiri, Iwami $\left(35^{\circ} 59.1^{\prime} \mathrm{N}, 134^{\circ} 31.0^{\prime} \mathrm{E}\right), 12 \mathrm{~m}, \mathrm{SCUBA}, 11$ October 2017, coll. Y. Ota, 1 male (pcl $3.1 \mathrm{~mm}$ ), TRPM-785.

Distribution. Japan, South China Sea, Papua New Guinea, and New Caledonia; depths of 1-54 m (Macpherson and Robainas-Barcia 2015). Japanese records include the Ryukyu Islands (Okinawa and Kume Islands), Izu Islands (Hachijo Island), and Tottori Prefecture (Kato and Okuno 2001, as Galathea sp. B; Osawa 2004; present study). The present specimen reveals the occurrence of this species in the Sea of Japan for the first time.

Habitat. Rock; dead and living coral; and coarse mud, sand and shell (Osawa 2004; Dong and Li 2010). The present specimen was collected from the underside of a rock.

Remarks. This galatheid can be regarded as a tropical shallow-water species, estimated from the known distribution. The uninterrupted mesogastric ridge between the first branchial marginal spines on the carapace and two rounded white spots at the base of the cheliped fingers are diagnostic for G. guttata, and these characters immediately distinguish the species from other local congeners such as G. orientalis Stimpson, 1858 and G. peitho Macpherson and RobainasBarcia, 2015, known from Tottrori and/or Shimane Prefectures (cf. Osawa et al. 2014b, 2015, 2018).
Family Munididae Ahyong, Baba, Macpherson, and Poore, 2010

Munida agave Macpherson and Baba, 1993

(Figs 2I, 3D)

Munida agave Macpherson and Baba, 1993: 387, figs 1, 2 (type locality: Philippines, MUSORTOM 2 stn 33, $13^{\circ} 32.3^{\prime} \mathrm{N}, 121^{\circ} 07.5^{\prime} \mathrm{E}$; $130-137 \mathrm{~m}$.); Macpherson 1997: 603; Baba 2005: 89, 258; Baba et al. 2008: 84 (compilation).

Material examined. Tottori Prefecture. Off Nagaobana $\left(35^{\circ} 55^{\prime} \mathrm{N}, 134^{\circ} 00^{\prime} \mathrm{E}\right)$, Tottori: $100 \mathrm{~m}$, beam trawl, 15 May 2018, coll. Y. Ota, 2 males (pcl 5.9, 6.0 mm), TRPM-786; $70 \mathrm{~m}$, beam trawl, 13 July 2018, coll. Y. Ota, 1 ovigerous female (pcl $7.5 \mathrm{~mm}$ ), TRPM-787; $100 \mathrm{~m}$, beam trawl, 13 July 2018, coll. Y. Ota, 1 ovigerous female (pcl $7.4 \mathrm{~mm}$ ), TRPM788; $70 \mathrm{~m}$, beam trawl, 17 April 2019, coll. Y. Ota, 1 female (pcl $5.3 \mathrm{~mm}$ ), TRPM-789.

Distribution. Japan, the Philippines, and Indonesia; depths of 89-549 m (Baba et al. 2008). Japanese records include Sagami Bay, and Tottori and Kagoshima Prefectures (Macpherson and Baba 1993; Baba 2005; present study). The present specimens reveal the first record of this species from the Sea of Japan.

Habitat. Hard bottom, rock (Baba 2005). The present specimens were collected from the muddy sand substrate.

Remarks. The present specimens of Munida agave were found together with another congener, $M$. pherusa Macpherson and Baba, 1993, in the same trawl catch collected from off Nagaobana, at depths of $80-100 \mathrm{~m}$. The latter species has been already recorded from the Sea of Japan, off Yamaguchi Prefecture (Komai et al. 2002). The two species are separated for each other by characters discussed by Macpherson and Baba (1993), as well as the fresh coloration. The bases of the rostrum and cheliped fingers have a white patch respectively in $M$. pherusa unlike in $M$. agave (Fig. 3D-F).

\section{Paramunida tricarinata (Alcock, 1894)}

[New standard Japanese name:

Mitsutoge-zarazara-chu-koshiori-ebi] (Figs 3G, 4)

\section{Restricted synonymy.}

Munida tricarinata Alcock, 1894: 324 (type locality: Andaman Sea, 205 m); Alcock and Anderson 1895: pl. 12, fig. 1.

Paramunida scabra (non Henderson, 1885): Wu et al. 1998: 145, figs 41, 42G; Macpherson 1993: 462 (in part).

Paramunida tricarinata: Baba 2005: 304; Baba et al. 2008: 175 (list of occurrences); Baba et al. 2009: 283, figs 260, 261; Cabezas et al. 2010: 56, figs 15H, 18I; McCallum et al. 2016: 216, figs $2 \mathrm{~B}, \mathrm{C}, 8$.

Material examined. Tottori Prefecture. Off Nagaobana $\left(35^{\circ} 55^{\prime} \mathrm{N}, 134^{\circ} 00^{\prime} \mathrm{E}\right)$, Tottori: $100 \mathrm{~m}$, beam trawl, 15 May 2018, coll. Y. Ota, 1 male (pcl $6.6 \mathrm{~mm}$ ), 1 ovigerous female 

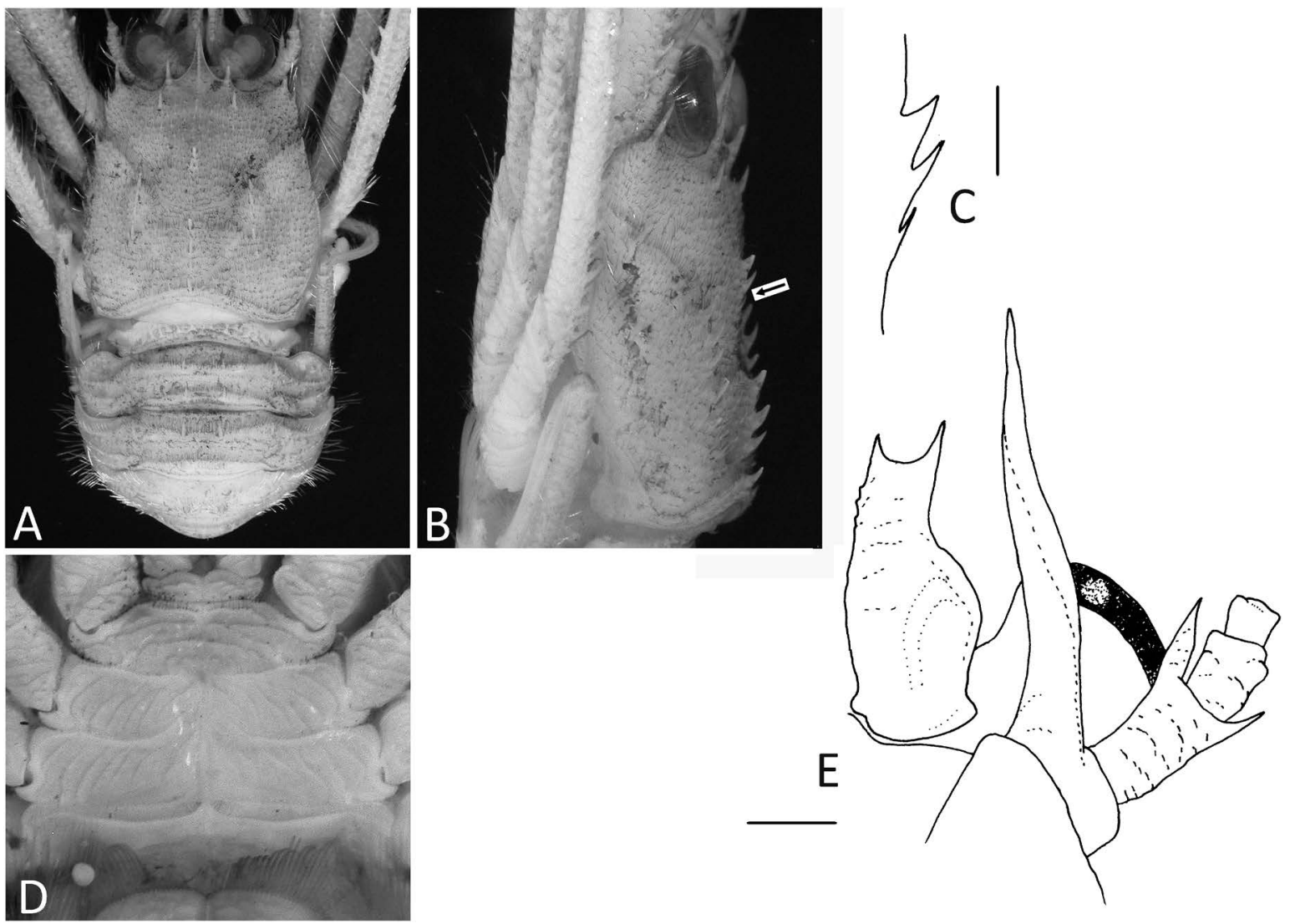

Fig. 4. Paramunida tricarinata (Alcock, 1894), ovigerous female (pcl $7.9 \mathrm{~mm}$ ), TRPM-790. A, carapace and abdomen, dorsal view; B, carapace, left lateral view (arrow showing third spine on midline of mesogastric region); C, spines on midline of mesogastric region, left lateral view; D, sternal plastron, ventral view; E, left eye, antennular article 1, and antennal peduncle, ventral view (setae omitted). Scale bars for $\mathrm{C}$ and E equal $1.0 \mathrm{~mm}$.

(pcl $7.9 \mathrm{~mm}$ ), TRPM-790; $100 \mathrm{~m}$, beam trawl, 20 August 2018, coll. Y. Ota, 1 female (pcl $6.2 \mathrm{~mm}$ ), 1 ovigerous female (pcl $.5 .5 \mathrm{~mm}$ ), TRPM-791; $120 \mathrm{~m}$, beam trawl, 20 August 2018, coll. Y. Ota, 1 female (pcl 6.3 mm), TRPM-792.

Distribution. Taiwan, Philippines, Andaman Sea, northwestern Australia, Maldives Islands, and Arabian Sea; depths of 187-384 m (McCallum et al. 2016). Newly recorded from Japanese waters.

Habitat. No previous records on the collection substrate, but vast majority of the previous specimens were collected by trawl, suggesting that they were probably on soft bottoms. The present specimens were collected from muddy sand substrates.

Remarks. The present material from the Sea of Japan agrees well with Taiwan and Philippine specimens of $P$. tricarinata reported by Baba et al. (2009) and Cabezas et al. (2010) in the following diagnostic features (Fig. 3): the rostral spine is larger than the supraocular spines; the carapace has a row of three spines in the midline of the mesogastric region and tufts of long and dense setae along the anterior branch of the cervical groove; the sternal plastron has numerous striae; the anterior prolongation of the antennal article 1 is spiniform and does not have a row of spines on the dorsal margin; the antennal article 2 is slightly longer than broad, the distomesial spine is spiniform and slightly overreaches the end of the antennal peduncle at most (in the present material, it reaches the end of the antennal peduncle), the distolateral spine never reaches the end of that article; and the antennal article 3 is slightly longer than broad. Unlike these specimens from Japan, Taiwan, and the Philippines, the antennal article 2 of the north-western Australian material reported by McCallum et al. (2016) has the distomesial spine extending far beyond the end of the antennal peduncle and the distolateral spine reaching or slightly exceeding the end of the article 3 , although the Tamura-Nei genetic divergence using the mitochondrial ND1 and 16S rRNA genes between specimens of $P$. tricarinata from north-western Australia and Taiwan is lower than those between sister taxa $(0.008 \pm 0.004$ vs. $0.018 \pm 0.004$ between $P$. ascella McCallum, Cabezas and Andreakis, 2016 and P. tricarinata; McCallum et al. 2016).

The size of the median spines in the mesogastric region of the carapace may vary in $P$. tricarinata. In the present material, the three spines on the mesogastric median row decrease in size posteriorly; the anterior two spines are strong and the third spine is smaller than the second or greatly reduced in size (Fig. 4B, C), as illustrated for a Philippine specimen by Cabezas et al. (2010: fig. 15H). In the illustrated specimens from Taiwan and north-western Australia (Baba et al. 2009: fig. 261a; McCallum et al. 2016: fig. 8A, B), the spines are subequal in size and the third spine is rather large. The anterior prolongation of the antennal article 1 is 
also proportionally shorter in the present material than the previously reported specimens. In the material examined, it overreaches the distal margin of the antennular article 1 by one third (Fig. 4E), instead of about half of its length in other described/illustrated specimens (Cabezas et al. 2010: fig. 18I; McCallum et al. 2016: fig. 8D).

Although literature records of $P$. tricarinata include western Indian Ocean localities (Laurie 1926; Tirmizi 1966, as Munida Leach, 1820; Baba 1990; Macpherson 1993), identities of these specimens were questioned by Cabezas et al. (2010).

In Japanese waters, three congeneric species, $P$. leptotes
Macpherson and Baba, 2009 (Baba 1982, 1986; as Munida proxima Henderson, 1885), P. scabra (Henderson, 1885), P. stichas Macpherson, 1993, are known (cf. Baba 2005; Macpherson and Baba 2009). Paramunida tricarinata is the fourth species of the genus recorded from Japan.

\section{Discussion}

Current knowledge on the fauna of Gebiidea and Anomura in "San'in" area

Four gebiidean species are hitherto known from the Japa-

Table 1. First records of anomuran species from Tottori Prefecture, "San'in" area, western Japanese coast of the Sea of Japan.

\begin{tabular}{|c|c|c|}
\hline Species & Voucher specimens & $\begin{array}{l}\text { Previous Japanese records in the } \\
\text { Sea of Japan }\end{array}$ \\
\hline \multicolumn{3}{|l|}{ Diogenidae } \\
\hline $\begin{array}{l}\text { Paguristes gonagrus } \\
\text { (H. Milne Edwards, 1836) }\end{array}$ & $\begin{array}{l}\text { Off Nagaobana }\left(35^{\circ} 55^{\prime} \mathrm{N}, 134^{\circ} 00^{\prime} \mathrm{E}\right) \text {, Tottori, } 50 \mathrm{~m} \text {, } \\
\text { beam trawl, } 20 \text { August } 2018,1 \text { male (sl } 6.4 \mathrm{~mm} \text { ), TRPM- } \\
782 \text { (Figs } 2 \mathrm{E}, 3 \mathrm{~A})\end{array}$ & No. \\
\hline Paguristes versus Komai, 2001 & $\begin{array}{l}\text { Off Nagaobana, Tottori, } 100 \mathrm{~m} \text {, beam trawl, } 15 \text { May } 2018 \text {, } \\
1 \text { male (sl } 5.8 \mathrm{~mm} \text { ), TRPM-783 (Figs 2F, 3B). }\end{array}$ & $\begin{array}{l}\text { Toyama Bay, Toyama Prefecture } \\
\text { (Kikuchi 1932, as P. kagoshimensis). }\end{array}$ \\
\hline \multicolumn{3}{|l|}{ Paguridae } \\
\hline Catapaguroides fragilis (Melin, 1939) & $\begin{array}{l}\text { Off Tajiri (“Yamadashi”, } 35^{\circ} 60.2^{\prime} \mathrm{N}, 134^{\circ} 31.1^{\prime} \mathrm{E} \text { ), Iwami, } \\
26 \mathrm{~m}, 4 \text { June } 2019,1 \text { ovigerous female (sl } 1.2 \mathrm{~mm} \text { ), } \\
\text { TRPM-793. }\end{array}$ & $\begin{array}{l}\text { Oki Islands, Shimane Prefecture } \\
\quad \text { (Osawa et al. 2015). }\end{array}$ \\
\hline $\begin{array}{l}\text { Nematopagurus australis } \\
\quad \text { (Henderson, 1888) }\end{array}$ & $\begin{array}{l}\text { Off Nagaobana, Tottori, } 100 \mathrm{~m} \text {, beam trawl, } 15 \text { May } 2018 \text {, } \\
1 \text { female (sl } 4.3 \mathrm{~mm} \text { ), TRPM-784 (Figs } 2 \mathrm{G}, 3 \mathrm{C} \text { ). }\end{array}$ & No. \\
\hline $\begin{array}{l}\text { Nematopagurus tricarinatus } \\
\quad \text { (Stimpson, 1858) }\end{array}$ & $\begin{array}{l}\text { Off Nagaobana, Tottori, } 50 \mathrm{~m} \text {, beam trawl, } 13 \text { July } 2018 \text {, } \\
1 \text { male (sl } 3.1 \mathrm{~mm}) \text {, TRPM-794. }\end{array}$ & $\begin{array}{l}\text { Oki Islands, Shimane Prefecture } \\
\quad \text { (Osawa et al. 2015). }\end{array}$ \\
\hline Pagurus conformis De Haan, 1849 & $\begin{array}{l}\text { Off Nagaobana, Tottori, } 100 \mathrm{~m} \text {, beam trawl, } 15 \text { May } 2018 \text {, } \\
1 \text { male (sl } 4.1 \mathrm{~mm} \text { ), TRPM-795. }\end{array}$ & $\begin{array}{l}\text { North of Nagato, Yamaguchi Prefecture } \\
\text { (Yokoya 1933, as Eupagurs). }\end{array}$ \\
\hline Pagurus constans (Stimpson, 1858) & $\begin{array}{l}\text { Off Nagaobana, Tottori, } 70 \mathrm{~m} \text {, beam trawl, } 15 \text { May } 2018 \text {, } \\
1 \text { male (sl } 9.5 \mathrm{~mm}) \text {, TRPM-796. }\end{array}$ & $\begin{array}{l}\text { Kyoto, Ishikawa, Niigata, Yamagata, } \\
\text { Akita, Aomori, and Hokkaido Pre- } \\
\text { fectures (cf. Motoh 2007). }\end{array}$ \\
\hline Pagurus erythrogrammus Komai, 2003 & $\begin{array}{l}\text { Off Tajiri ("Yamadashi”), Iwami, } 26 \mathrm{~m}, 4 \text { June 2019, } 1 \text { male } \\
\quad \text { (sl } 1.8 \mathrm{~mm} \text { ), TRPM-797. }\end{array}$ & $\begin{array}{l}\text { Izumo and Matsue, Shimane Prefecture } \\
\text { (Osawa et al. 2014b); Wakasa Bay, } \\
\text { Kyoto Prefecture (Asakura 2006); } \\
\text { Echizen, Koshino, and Mikuni, } \\
\text { Fukui Prefecture (Komai 2003) }\end{array}$ \\
\hline Pagurus nipponensis (Yokoya, 1933) & $\begin{array}{l}\text { Off Nagaobana, Tottori, } 100 \mathrm{~m} \text {, beam trawl, } 17 \text { April 2019, } \\
1 \text { ovigerous female (sl } 5.9 \mathrm{~mm} \text { ), TRPM-798 (Fig. } 3 \mathrm{H}) \text {. }\end{array}$ & $\begin{array}{l}\text { Wakasa Bay, Kyoto Prefecture; Shonai- } \\
\text { hama, Yamagata Prefecture (Asakura } \\
\text { 2006); Tsugaru Strait, Aomori Pre- } \\
\text { fecture (Yokoya 1933, as Eupagurus) }\end{array}$ \\
\hline Pagurus quinquelineatus Komai, 2003 & $\begin{array}{l}\left.\text { Off Haneo-misaki (“Goishiwara”, } 35^{\circ} 60.4^{\prime} \mathrm{N}, 134^{\circ} 33.9^{\prime} \mathrm{E}\right) \text {, } \\
\text { Iwami, } 10 \mathrm{~m}, 13 \text { August 2018, } 1 \text { male (sl } 1.7 \mathrm{~mm} \text { ), TRPM- } \\
799 .\end{array}$ & $\begin{array}{l}\text { Izumo, Shimane Prefecture (Osawa et } \\
\text { al. 2016); Wakasa Bay, Kyoto Prefec- } \\
\text { ture (Asakura 2006); Echizen, Fukui } \\
\text { Prefecture (Komai 2003). }\end{array}$ \\
\hline $\begin{array}{l}\text { Porcellanopagurus nihonkaiensis Takeda, } \\
\quad 1985\end{array}$ & $\begin{array}{l}\text { Off Tajiri ("Yamadashi"), Iwami, } 15 \text { m, } 20 \text { September } 2018 \text {, } \\
1 \text { ovigerous female (sl } 1.9 \mathrm{~mm} \text { ), TRPM- } 800 .\end{array}$ & $\begin{array}{l}\text { Iida Bay, Ishikawa Prefecture } \\
\quad \text { (Takeda 1985). }\end{array}$ \\
\hline \multicolumn{3}{|l|}{ Galatheidae } \\
\hline Galathea guttata Osawa, 2004 & $\begin{array}{l}\text { Off Tajiri }\left(35^{\circ} 59.1^{\prime} \mathrm{N}, 134^{\circ} 31.0^{\prime} \mathrm{E}\right) \text {, Iwami, } 12 \mathrm{~m}, 11 \text { October } \\
\text { 2017, } 1 \text { male (pcl } 3.1 \mathrm{~mm}) \text {, TRPM-785 (Fig. } 2 \mathrm{H}) \text {. }\end{array}$ & No. \\
\hline \multicolumn{3}{|l|}{ Munididae } \\
\hline Bathymunida brevirostris (Yokoya, 1933) & $\begin{array}{l}\text { Off Nagaobana, Tottori, } 80 \mathrm{~m} \text {, beam trawl, } 10 \text { September } \\
\text { 2019, } 1 \text { female (pcl 5.4 mm), TRPM-801 (Fig. 3I). }\end{array}$ & $\begin{array}{l}\text { Off Hagi, Yamaguchi Prefecture } \\
\quad \text { (Komai et al. 2002). }\end{array}$ \\
\hline Munida agave Macpherson and Baba, 1993 & $\begin{array}{l}\text { Off Nagaobana, Tottori, } 100 \mathrm{~m} \text {, beam trawl, } 13 \text { July } 2018 \text {, } \\
1 \text { ovigerous female (pcl } 7.4 \mathrm{~mm} \text { ), TRPM-788 (Fig. } 2 \mathrm{I}) \text {. }\end{array}$ & No. \\
\hline $\begin{array}{l}\text { Munida pherusa Macpherson and Baba, } \\
1993\end{array}$ & $\begin{array}{l}\text { Off Nagaobana, Tottori, } 100 \mathrm{~m} \text {, beam trawl, } 20 \text { August } 2018 \text {, } \\
1 \text { male (pcl } 6.6 \mathrm{~mm}), 1 \text { ovigerous female (pcl } 7.7 \mathrm{~mm}) \\
\text { TRPM-802 (Fig. 2E, F). }\end{array}$ & $\begin{array}{l}\text { Off Nagato and Hagi, Yamaguchi Pre- } \\
\text { fecture (Komai et al. 2002). }\end{array}$ \\
\hline Paramunida tricarinata (Alcock, 1894) & $\begin{array}{l}\text { Off Nagaobana, Tottori, } 100 \mathrm{~m} \text {, beam trawl, } 15 \text { May } 2018 \text {, } \\
1 \text { ovigerous female ( } \mathrm{pcl} 7.9 \mathrm{~mm}) \text {, TRPM-790 (Figs } 3 \mathrm{G}, 4) \text {. }\end{array}$ & No. \\
\hline
\end{tabular}


Table 2. Anomuran species recorded from the entire "San-in" area (cf. Motoh 2007, with deletion of wrong record of Pagurus middendorffii Brandt, 1851 from Kyoto Prefecture; Osawa et al. 2015, 2016, 2018; present study). * Occurrence records need to be verified.

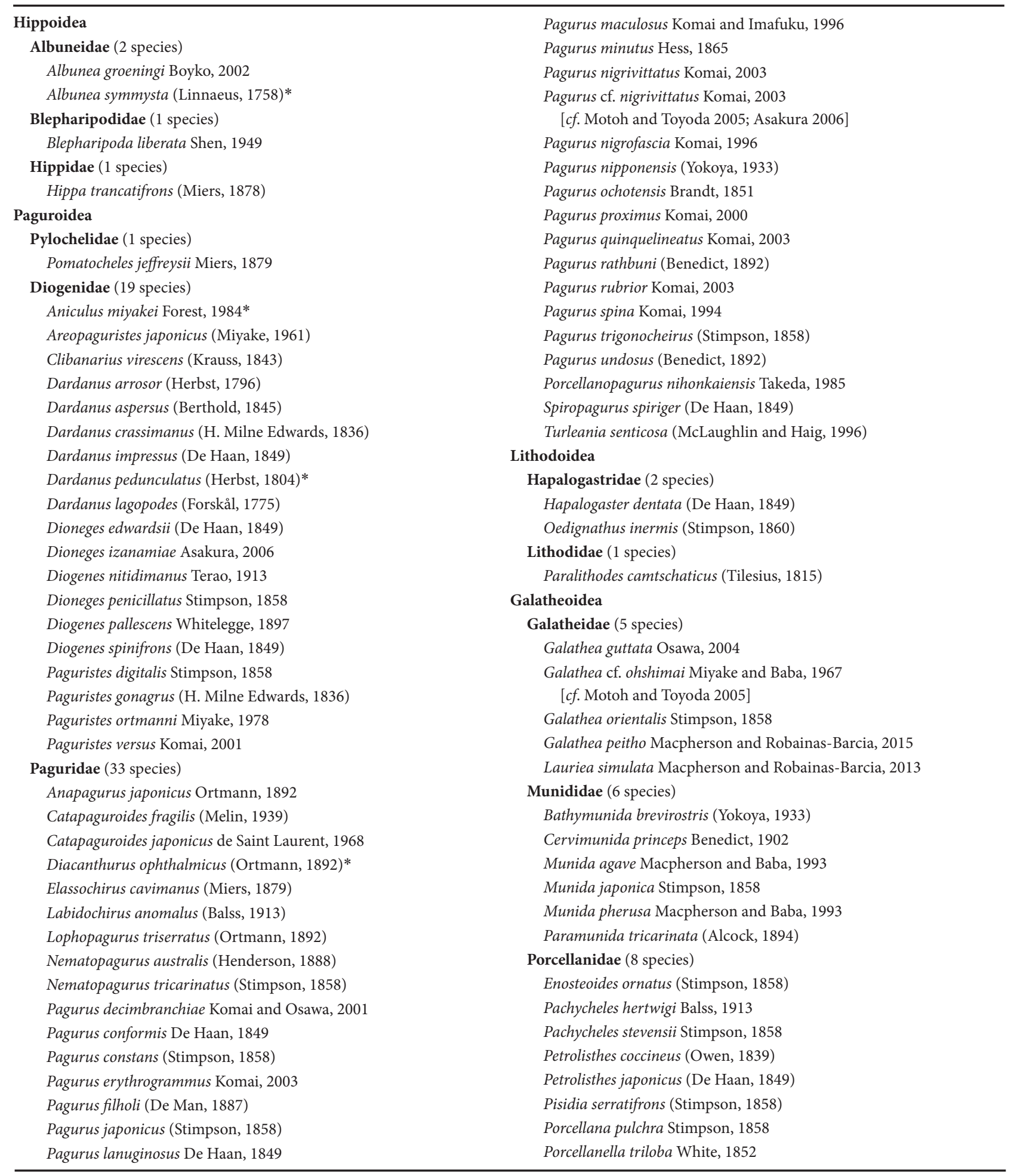

nese coast of the Sea of Japan: Naushonia japonica Komai, 2004; Upogebia issaeff; U. major; and U. yokoyai Makarov, 1938 (e.g., Miyake et al. 1962; Sakai 1982; Komai 2004; Osawa et al. 2014a). Austinogebia narutensis is the fifth gebiidean species in this region. The distribution of the three Upogebia species extends north to the Russian coast (Peter the Great Bay; Marin et al. 2013), and the records of the three species from "San'in" area (Yamaguchi, Shimane, Tottori, Hyogo, and Kyoto Prefectures; Fig. 1B), the western
Japanese coast of the Sea of Japan, are respective shown as follows: Hyogo for U. issaeff, Tottori for U. major, and Shimane for U. yokoyai (Miyake et al. 1962; Sakai 1982; Osawa et al. 2014a). With regard to Austinogebia, A. monospina Liu and Liu, 2012 and A. wuhsienweni are recorded from the southwestern coast of Korea (Jeollanam-do), north of Tsushima Strait (Kim and Kim 2017), but A. narutensis has not been recorded from the continental coast of the Sea of Japan. In Japan, A. wuhsienweni is recorded only from Na- 
gasaki Prefecture (Sakai 2006). Naushonia japonica, the remaining gebiidean species hitherto recorded from the Sea of Japan, has been known only from Shimonoseki, Yamaguchi Prefecture (type locality; Komai 2004), and Katsuura, Chiba Prefecture on the Pacific coast of Honshu mainland, central Japan (Komai and Anker 2015).

With regard to Anomura, a series of recent studies has revealed that 54 species (26 genera in nine families) occur in Shimane Prefecture including the Oki Islands off the "San'in" coast (cf. Osawa et al. 2014b, 2015, 2016, 2018). Prior to Osawa et al. (2014b), the knowledge on the faunal composition of the area was very poor because only 21 species were known from there. As shown in Introduction, Nishimura (1992) discussed on seven zoogeographical (zooclimatic) zones categorized in Japanese waters (tropical, subtropical, warm temperate, moderate temperate, cool temperate, subboreal, and boreal zones). Species primary found in the three temperate zones consist of East Asian endemic elements, whereas those showing tropical or subtropical distribution correspond to Indo-West Pacific elements. Osawa et al. (2014b) preliminarily interpreted that the anomuran fauna of the coast of Shimane Prefecture is composed primarily of the East Asian endemic elements (59\%; 32 species of the total species number, 54) and the Indo-West Pacific elements [31\%; 17 species of the total species number; all the species numbers are supplemented by Osawa et al. $(2015,2016,2018)]$. This is not contradicted by the fact that the area around Shimane Prefecture is located at temperate zone of East Asia and is likely a boundary between the warm temperate and moderate temperate zones in the coast of the Sea of Japan suggested by Nishimura (1992).

Meanwhile, 31 anomuran species are hitherto recorded from Tottori Prefecture which is presently studied area and situated east to Shimane Prefecture [cf. Motoh 2007: table 2; Osawa et al. 2015: table 1; with their inadvertently omitted record of Lophopagurus triserratus (Ortmann, 1892) from off the prefecture by Yokoya 1933, as Eupagurus Brandt, 1851]. In addition to these species, examination of specimens recently collected from Tottori Prefecture by the second author has shown that 16 species, including five species new to the Sea of Japan reported above, are new records from the area (Table $1 ; 47$ species in total). The increase of the recorded species is due to the sampling effort in the sublittoral zone using scuba and trawls.

The inventory of anomuran fauna in the areas of Shimane and Tottori Prefectures is still incomplete, and knowledge on the faunal composition is still limited. There is little doubt that future study will reveals the presence of more species in the areas, particularly from the sublittoral zone between 10 and $200 \mathrm{~m}$ where only a few reports on anomurans are present (cf. Osawa et al. 2014b, 2015). Including published records from the other three prefectures (Yamaguchi, Hyogo, and Kyoto), 79 anomuran species are known from the coasts and off-shores of entire "San'in" area, but the records of some species need to be verified because no positive information on the species identification were given for the reported material (Table 2). For example, "Menaga-hon- yadokari”, Japanese name for Diacanthurus ophthalmicus (Ortmann, 1892), was recorded from the eastern coast of the estuarine lake Nakaumi (Tottori Prefecture) by Yonago City (1997: table 2-5, written by Japanese and the sole record of the species from "San'in" area), but the pagurid species is unexceptionally known from the off-shore at depths greater than $65 \mathrm{~m}$ (cf. McLaughlin et al. 2007). The material reported by Yonago City (1997) high probably belongs to Pagurus filholi (De Man, 1887) or P. minutus Hess, 1865, because these are only hermit crab species found in the intertidal or shallow subtidal zone of Nakaumi and its adjacent area (Osawa et al. 2014b). These show that it is premature at present to reasonably discuss on the faunal and biogeographical characters of the "San'in" area. Reliable information on species based on the specimens collected and allowed re-verification is needed to know precise faunal composition of the local area.

\section{Acknowledgments}

We thank the staff of the Tottori Prefectural Fisheries Center and the local diving shop "Blueline Tajiri" for helping the second author to collect specimens herein reported. The field research of the second author and the present study were partially supported by the grant of Tottori Prefecture to the San'in Kaigan Geopark Museum of Earth and Sea. Comments and suggestions of two anonymous reviewers were very helpful to improve this manuscript.

\section{References}

Ahyong, S. T., Baba, K., Macpherson, E., and Poore, G. C. B. 2010. A new classification of the Galatheoidea (Crustacea: Decapoda: Anomura). Zootaxa 2676: 57-68.

Alcock, A. 1894. Natural history notes from H.M. Royal Indian Marine Survey Steamer "Investigator", commander R.F. Hoskin, R.N., commanding.-Series II, No. 1. On the results of deep-sea dredging during the season of 1890-91 (continued). Annals and Magazine of Natural History, Series 6 13: 321-334.

Alcock, A. 1905. Catalogue of the Indian Decapod Crustacea in the Collections of the Indian Museum, Vol. 2. Anomura. Fasc. I. Pagurides. Indian Museum, Calcutta, xi+197 pp.

Alcock, A. and Anderson, A. R. S. 1895. Crustacea, Part III. Pls 9-15. In: Illustrations of the Zoology of the Royal Indian Marine Surveying Steamer Investigator, under the Command of Commander A. Carpenter, R.N., D.S.O., of the Late Commander R.F. Hoskyn, R.N., and of Commander C.F. Oldham. Trustees of the Indian Museum, Calcutta.

Asakura, A. 2006. Shallow water hermit crabs of the families Pylochelidae, Diogenidae and Paguridae (Crustacea: Decapoda: Anomura) from the Sea of Japan, with the description of a new species of $\mathrm{Di}$ ogenes. Bulletin of the Toyama Science Museum 29: 23-103.

Baba, K. 1982. Deep-sea galatheidean Crustacea (Decapoda, Anomura) taken by the R/V Soyo-Maru in Japanese waters. II Family Galatheidae. Bulletin of the National Science Museum, Tokyo, Series A 8: 103-120.

Baba, K. 1986. Reptantia. Pp. 148-23 [In Japanese], 279-316 [In English]. In: Baba, K., Hayashi, K., and Toriyama, M. (Eds) Decapod 
Crustaceans from Continental Shelf and Slope around Japan. The Intensive Research of Unexploited Fishery Resources on Continental Slopes. Japan Fisheries Resource Conservation Association, Tokyo.

Baba, K. 1990. Chirostylid and galatheid crustaceans of Madagascar (Decapoda, Anomura). Bulletin du Muséum national d'Histoire naturelle, Paris (4e série), Section A 11: 921-975.

Baba, K. 2005. Deep-sea chirostylid and galatheid crustaceans (Decapoda: Anomura) from the Indo-West Pacific, with a list of species. Galathea Reports 20: 1-317.

Baba, K., Macpherson, E., Lin, C.-W., and Chan, T.Y. 2009. Crustacean Fauna of Taiwan. Squat lobsters (Chirostylidae and Galatheidae). National Taiwan Ocean University, Keelung, 311 pp.

Baba, K., Macpherson, E., Poore, G. C. B., Ahyong, S. T., Bermudez, A., Cabezas, P., Lin, C.-W., Nizinski, M., Rodrigues, C., and Schnabel, K. E. 2008. Catalogue of squat lobsters of the world (Crustacea: Decapoda: Anomura-families Chirostylidae, Galatheidae and Kiwaidae). Zootaxa 1905: 1-220.

Borradaile, L. A. 1903. On the classification of the Thalassinidea. Annals and Magazine of Natural History, Series 7 12: 534-551.

Cabezas, P., Macpherson, E., and Machordom, A. 2010. Taxonomic revision of the genus Paramunida Baba, 1988 (Crustacea: Decapoda: Galatheidae): a morphological and molecular approach. Zootaxa 2712: 1-60.

Dong, C. and Li, X. 2010. Reports of Galathea Fabricius, 1793 (Crustacea: Decapoda: Anomura: Galatheidae) from Chinese waters, with descriptions of two new species. Zootaxa 2687: 1-28.

Henderson, J. R. 1888. Report on the Anomura collected by H.M.S. Challenger during the years 1873-76. Scientific Results of the Exploratory Voyage of HMS Challenger, (Zoology), Vol. 27. Her Majesty's Stationary Office, Edinburgh etc, $x i+221$ pp.

Itani, G. 2004. Distribution of intertidal upogebiid shrimp (Crustacea: Decapoda: Thalassinidea) in Japan. Contributions from the Biological Laboratory, Kyoto University 29: 383-399.

Kato, S. and Okuno, J. 2001. Shrimps and Crabs of Hachijo Island. TBSBritannica, Tokyo, 157 pp. [In Japanese]

Kikuchi, K. 1932. Decapod Crustaceans of Toyama Bay. List of Faunal Research in Toyama Bay. Toyama Kyoiku, Toyama, 23 pp. [In Japanese]

Kim, H. S. 1973. Illustrated Encyclopedia of Fauna \& Flora of Korea, Vol. 14. Anomura and Brachyura. Samhwa Publishing Company, Ltd., Seoul, 694 pp. [In Korean]

Kim, J. N. and Kim, M. H. 2017. Invertebrate Fauna of Korea, Vol. 21 (3). Hermit Crabs II. National Institute of Biological Resources, Incheon, $133 \mathrm{pp}$.

Kinoshita, K. and Itani, G. 2005. Interspecific differences in the burrow morphology between the sympatric mud shrimps, Austinogebia narutensis and Upogebia issaeffi (Crustacea: Thalassinidea: Upogebiidae). Journal of the Marine Biological Association of the United Kingdom 85: 943-947.

Komai, T. 2001. A review of the north-western Pacific species of the genus Paguristes (Decapoda: Anomura: Diogenidae), I. Five species initially reported by Ortmann (1892) from Japan. Journal of Natural History 35: 357-428.

Komai, T. 2003. Reassessment of Pagurus pilosipes (Stimpson), supplemental description of $P$. insulae Asakura, and descriptions of three new species of Pagurus from East Asian waters (Crustacea: Decapoda: Anomura: Paguridae). Natural History Research 7: 115-166.

Komai, T. 2004. Rare mud shrimp genus Naushonia Kingsley (Decapoda: Thalassinidea: Laomediidae) from Japan: description of a new species and new record of N. lactoalbida Berggren. Crustacean Research 33: 15-26.

Komai, T. 2009. A review of the northwestern Pacific species of the genus Paguristes (Decapoda: Anomura: Diogenidae). II. Species tansferred to the genus Stratiotes, with descriptions of two new species. Natural History Research 10: 59-92.

Komai, T. 2010. A review of the northwestern Pacific species of the genus Paguristes (Decapoda: Anomura: Diogenidae). III. Clarification of the identity of a species heretofore referred to Paguristes balanophilus Alcock and descriptions of two new species from Japan. Natural History Research 11: 9-33.

Komai, T. and Anker, A. 2015. Additional records of the laomediid mud-shrimp genus Naushonia Kingsley, 1897 (Crustacea: Decapoda: Gebiidea), with a revised identification key. Zootaxa 3974: 341-360.

Komai, T., Ohtsuka, S., Nakaguchi, K., and Go, A. 2002. Decapod crustaceans collected from the southern part of the Sea of Japan in 2000-2001 using TRV Toyoshio-maru. Natural History Research 7: 19-73.

Komai, T. and Takeda, M. 2006. A review of the pagurid hermit crab (Decapoda: Anomura: Paguroidea) fauna of the Sagami Sea, Central Japan. Memoirs of the National Science Museum, Tokyo 41: 71-144.

Latreille, P. A. 1802. Histoire Naturelle, Générale et Particulière des Crustacés et des Insectes. Ouvrage Faisant Suite à l'Histoire Naturelle Générale et Particulière, Composée par Leclerc de Buffon, et Rédigée par C.S. Sonnini, Membre de Plusieurs Sociétés Savantes. Familles Naturelles des Genres, Vol. 3. F. DuFart, Paris, 467 pp.

Laurie, R. D. 1926. Reports of the Percy Sladen Trust Expedition to the Indian Ocean in 1905, under the leadership of Mr. J. Stanley Gardiner, M. A. Vol. 8, No. VI.-Anomura collected by Mr. J. Stanley Gardiner in the western Indian Ocean in H. M. S. Sealark. Transactions of the Zoological Society of London, Series 2 (Zoology) 19: $121-167$.

Liu, W. and Sha, Z. 2015. A new species of the genus Austinogebia Ngoc-Ho, 2001 (Decapoda, Gebiidea, Upogebiidae) from the Bohai Sea, China. Crustaceana 88: 701-708.

MacLeay, W. S. 1838. On the brachyurous decapod Crustacea brought from the Cape by Dr. Smith. Pp. 53-71, 2 pls. In: Smith, A. (Ed.) Illustrations of the Annulosa of South Africa; being a Portion of the Objects of Natural History chiefly Collected during an Expedition into the Interior of South Africa, under the Direction of Dr. Andrew Smith, in the Years 1834, 1835. and 1836; Fitted out by "The Cape of Good Hope Association for Exploring Central Africa". Smith, Elder, and Co., London.

Macpherson, E. 1993. Crustacea Decapoda: species of the genus Paramunida Baba, 1988 (Galatheidae) from the Philippines, Indonesia and New Caledonia. In: Crosnier, A. (Ed.) Résultats des Campagnes MUSORSTOM, Vol. 10. Mémoires du Muséum National d'Histoire Naturelle, Paris 156: 443-473.

Macpherson, E. 1997. Crustacea Decapoda: species of the genera Agononida Baba \& de Saint Laurent, 1996 and Munida Leach, 1820 (Galatheidae) from the KARUBAR cruise. In: Crosnier, A. and Bouchet, P. (Eds) Résultats des Campagnes MUSORSTOM, Vol. 16. Mémoires du Muséum National d'Histoire Naturelle, Paris 172: 597-612.

Macpherson, E. and Baba, K. 1993. Crustacea Decapoda: Munida japonica Stimpson, 1858, and related species (Galatheidae). In: Crosnier, A. (Ed.) Résultats des Campagnes MUSORSTOM, Vol. 10. Mémoires du Muséum National d'Histoire Naturelle, Paris 156: 381-420.

Macpherson, E. and Baba, K. 2009. New species of squat lobsters of the genera Agononida and Paramunida (Crustacea: Decapoda: Anomura: Galatheidae) from the western Pacific. Zootaxa 2024: 56-68.

Macpherson, E. and Robainas-Barcia, A. 2015. Species of the genus Galathea Fabricius, 1793 (Crustacea, Decapoda, Galatheidae) from the Indian and Pacific Oceans, with descriptions of 92 new species. Zootaxa 3913: 1-335. 
Marin, I. 2016. Notes on holotypes of hermit crabs (Decapoda: Anomura: Paguroidea) deposited in the collection of Zoological $\mathrm{Mu}$ seum of RAS (Saint-Petersburg, Russia) with remarks on hermit crab diversity along the Russian coast of the Sea of Japan. Zootaxa 4105: 171-180.

Marin, I. N., Korn, O. M., and Kornienko, E. S. 2013. Upogebia yokoyai Makarov, 1938 (Decapoda: Upogebiidae): a gebiid shrimp species new to the fauna of the Sea of Japan. Russian Journal of Marine Biology 39: 221-226. [In Russian with English abstract]

McCallum, A. W., Cabezas, P., and Andreakis, N. 2016. Deep-sea squat lobsters of the genus Paramunida Baba, 1988 (Crustacea: Decapoda: Munididae) from north-western Australia: new records and description of three new species. Zootaxa 4173: 201-224.

McLaughlin, P. A. 1997. Crustacea Decapoda: Hermit crabs of the family Paguridae from the KARUBAR cruise in Indonesia. In: Crosnier, A. and Bouchet, P. (Eds) Resultats des Campagnes MUSORSTOM, Vol. 16. Mémoires du Muséum National d'Histoire Naturelle, Paris 172: 433-572.

McLaughlin, P. A. 2002. A review of the hermit crab (Decapoda: Anomura: Paguridea) fauna of southern Thailand, with particular emphasis on the Andaman Sea, and descriptions of three new species. In: Bruce, N., Berggren, M., and Bussawarit, S. (Eds) Proceedings of the International Workshop on the Crustacea in the Andaman Sea, Phuket Marine Biological Center 29 November-20 December, 1998. Phuket Marine Biological Center, Special Publication 23: 385-460.

McLaughlin, P. A. 2004. A review of the hermit crab genus Nematopagurus A. Milne-Edwards and Bouvier, 1892 and the descriptions of five new species. In: Marshall, B. and Richer de Forges, B. (Eds) Tropical Deep-Sea Benthos, Vol. 23. Mémoires du Muséum National d'Histoire Naturelle, Paris 191: 151-229.

McLaughlin, P. A., Rahayu, D. L., Komai, T., and Chan, T.-Y. 2007. A Catalog of the Hermit Crabs (Paguroidea) of Taiwan. National Taiwan Ocean University, Keelung, viii +365 pp.

Milne Edwards, H. 1836. Observations zoologiques sur les Pagures et description d'un nouveau genre de la tribu des Paguriens. Annales des Sciences Naturelle Zoologie, Paris, Série 2 6: 257-288.

Minemizu, R. 2000. Marine Decapod and Stomatopod Crustaceans mainly from Japan. Bun'ichi-Sogo Publication, Ltd., Tokyo, 344 pp. [In Japanese]

Miyake, S. 1978. The Crustacean Anomura of Sagami Bay. Biological Laboratory, Imperial Household, Tokyo, 200 [In English]+161 [In Japanese] pp.

Miyake, S. 1982. Japanese Crustacean Decapods and Stomatopods in Color, Vol. 1. Macrura, Anomura, and Stomatopoda. Hoikusha Publishing Co., Ltd., Osaka, 261 pp. [In Japanese]

Miyake, S., Sakai, K., and Nishikawa, S. 1962. A faunal-list of the decapod Crustacea from the coasts washed by the Tsushima warm current. Records of Oceanographic Works in Japan, Special Number 6: 121-131.

Motoh, H. 2007. Anomuran Decapoda in the Sea of Japan-I. A check list based on literatures. Report of the Noto Marine Center 13: 2132. [In Japanese with English abstract]

Motoh, H. and Toyoda, K. 2005. Anomuran Decapoda from Kyoto Prefecture, Sea of Japan. Report of the Noto Marine Center 11: 43-49.

Ngoc-Ho, N. 1994. Notes on some Indo-Pacific species of Upogebiidae with descriptions of four new species (Crustacea: Thalassinidea). Memoirs of the Queensland Museum 35: 193-216.

Ngoc-Ho, N. 2001. Austinogebia, a new genus in the Upogebiidae and rediagnosis of its close relative, Gebiacantha Ngoc-Ho, 1989 (Crustacea: Decapoda: Thalassinidea). Hydrobiologia 449: 41-58.

Nishimura, S. 1992. Distribution of marine animals in Japanese waters. Pp. xi-ix. In: Nishimura, S. (Ed.) Guide to Seashore Animals of Japan with Color Pictures and Keys, Vol. 1. Hoikusha, Osaka. [In
Japanese]

Ortmann, A. 1892. Die Decapoden-Krebse des Strassburger Museum, mit besonderer Berucksichtigung der von Herrn Dr. Doederlein bei Japan und bei den Liu-Kiu-Inseln gesammelten und zur Zeit im Strassburger Museum aufbewahrten Formen. IV. Die Abtheilungen Galatheidea und Paguridea. Zoologishen Jahrbüchern. Abtheilung für Systematik, Geographie und Biologie der Thiere 6: 241-326.

Osawa, M. 2004. A new shallow-water species of the genus Galathea (Decapoda: Anomura: Galatheidae) from the Ryukyu and Izu Islands, Japan. Crustacean Research 33: 92-102.

Osawa, M., Komatsu, H., Kuwabara, T., and Kurata, K. 2015. Additional records of Anomura (Crustacea: Decapoda) from Shimane Prefecture, western Japan. Bulletin of the Hoshizaki Green Foundation 18: 151-159. [In Japanese with English abstract]

Osawa, M., Kuwabara, T., and Kurata, K. 2014a. Ghost and mud shrimps (Crustacea: Decapoda: Callianassidae, Upogebiidae) from Shimane Prefecture, western Japan. Bulletin of the Hoshizaki Green Foundation 17: 197-206. [In Japanese with English abstract]

Osawa, M., Kuwabara, T., and Kurata, K. 2016. Two species of Anomura (Crustacea: Decapoda) from Shimane Prefecture, western Japan. Bulletin of the Hoshizaki Green Foundation 19: 201-204. [In Japanese with English abstract]

Osawa, M., Kuwabara, T., and Kurata, K. 2018. First record of Galathea peitho Macpherson and Robainas-Barcia, 2015 (Crustacea: Decapoda: Anomura: Galatheidae) from the Sea of Japan. Bulletin of the Hoshizaki Green Foundation 21: 91-95. [In Japanese with English abstract]

Osawa, M., Kuwabara, T., Yoshida, Y., and Kurata, K. 2014b. Anomuran Crustacea of Shimane Prefecture, western Japan. Bulletin of the Hoshizaki Green Foundation 17: 207-236. [In Japanese with English abstract]

Rahayu, D. L. and Forest, J. 2009. Le genre Paguristes Dana aux Philippines avec la description de deux nouvelles espéces (Decapoda, Anomura, Diogenidae). Crustaceana 82: 1307-1338.

Rahayu, D. L. and McLaughlin, P. A. 2006. Clarifications of the identities of Paguristes balanophilus and P. calvus Alcock (Decapoda, Anomura, Paguroidea, Diogenidae) and the description of another broadly distributed new species. Zoosystema 28: 865-886.

Sakai, K. 1982. Revision of Upogebiidae (Decapoda, Thalassinidea) in the Indo-West Pacific region. Researches on Crustacea, Special Number 1: 1-106.

Sakai, K. 1984. A new record of Upogebia spinifrons (Haswell, 1882) (Decapoda, Thalassinidea) from Naruto, Japan, showing possible hermaphroditism. Crustaceana 47: 209-214.

Sakai, K. 1986. On Upogebia narutensis. a new thalassinid (Decapoda, Crustacea) from Japan. Researches on Crustacea 15: 23-28.

Sakai, K. 2006. Upogebiidae of the world (Decapoda, Thalassinidea). Crustaceana Monographs 6: 1-185.

Saint Laurent, M. de. 1979. Vers une nouvelle classification des Crustacés Décapodes Reptantia. Bulletin de l'Office National des Pêches République Tunisienne, Ministere de l'Agriculture 3: 15-31.

Samouelle, G. 1819. The Entomologist's Useful Compendium; or an Introduction to the Knowledge of British Insects, Comprising the Best Means of Obtaining and Preserving Them, and a Description of the Apparatus Generally Used; together with the Genera of Linné, and the Modern Method of Arranging the Classes Crustacea, Myriapoda, Spiders, Mites and Insects, from Their Affinities and Structure, according to the Views of Dr. Leach. Also an Explanation of the Terms Used in Entomology; a Calendar of the Times of Appearance and Usual Situations of Near 3,000 Species of British Insects; with Instructions for Collecting and Fitting up Objects for the Microscope. London, $496 \mathrm{pp}$. 
Sato, M., Kato, T., Seike, K., and Itani, G. 2016. Records of a scale worm, Hesperonoe hwanghaiensis (Annelida: Polynoidae) from eastern Japan. Taxa, Proceedings of the Japenese Society of Systematic Zoology 41: 30-39. [In Japanese with English abstract]

Takeda, M. 1985. Occurrence of a new hermit crab of the genus Porcellanopagurus in the Sea of Japan. Memoirs of the National Science Museum, Tokyo 18: 141-144.

Takeda, M., Furuta, S., Miyanaga, T., Tamura, A., and Wada, T. 2011. Crabs from the southwestern Sea of Japan along Tottori Prefecture and its vicinity, Japan. Bulletin of the Tottori Prefectural Museum 48: 29-94. [In Japanese with English abstract]

Tirmizi, N. M. 1966. Crustacea: Galatheidae. The John Murray Expedi- tion 1933-34. Scientific Reports 11: 167-234.

Yokoya, Y. 1933. On the distribution of decapod Crustacea inhabiting the continental shelf around Japan, chiefly based upon the materials collected by S.S. "Soyo Maru" during the years 1923-1930. Journal of the College of Agriculture, Tokyo Imperial University 12: 1-236.

Yonago City. 1997. IV. Fish and shellfish. Pp. 349-375. In: History of Yonago City, Vol. 6, Nature. Editorial Council, Yonago.

Wu, M.-F., Chan, T.-Y., and Yu, H.-P. 1998. On the Chirostylidae and Galatheidae (Crustacea: Decapoda: Galatheidea) of Taiwan. Annual of Taiwan Museum 40: 75-153. [In Chinese with English abstract] 